\title{
Geotechnical and Mineralogical Characterization of Clay Deposits in Parts of Southwestern Nigeria
}

\author{
Ademila, O. * and Adebanjo, O. J. \\ Department of Earth Sciences, Adekunle Ajasin University, Akungba-Akoko, Nigeria \\ Email: omowumi.ademila@aaua.edu.ng
}

\begin{abstract}
An engineering geological study was undertaken to determine the geotechnical properties and mineralogy of Erusu clay, southwestern Nigeria with a view to infer their suitability for industrial applications and provide background information for further economic assessment of the deposits. Clay soils from four different locations of the study area were subjected to geotechnical test while X-ray diffraction method was employed for the mineralogical analysis. The clays have low to moderate plasticity and contain quantity amounts of fines which make them suitable for sanitary landfill liners. The results of the compaction and CBR show its unsuitability for use as sub-base, base course and subgrade materials in road construction. X-ray diffraction analysis detected the presence of mixed layer clay mineral illite-smectite (rectorite), montmorillonite, halloysite (hydrated) and kaolinite. These clay minerals have negative influence on its use as aggregates in construction works but suitable for the production of ceramics, structural blocks, bricks, roof and floor tiles.
\end{abstract}

Keywords: Mineralogical characterization, geotechnical properties, clay deposits, refractory, industrial application.

\section{Introduction}

Rocks in Erusu area have been subjected to varying degrees of weathering which led to the formation of clay deposits. Clays are found in nature as a rock or soil, and clays exhibiting rock-like behaviour may transform to soil-like within a time interval of less than 1-70 years [1]. Clays are valuable resources in agriculture, engineering and structural ceramic industries for the manufacture of domestic and commercial products. Clay bodies are widely distributed on the Precambrian basement complex of Nigeria [2]. Clays are geological materials having particle size of less than 2 microns and the family of minerals have similar chemical compositions and common crystal structural characteristics [3]. Clays may also contain other minerals which may impart plasticity [4]. Chemical weathering of feldspars, micas and limestones can form clay minerals which belong to phyllosilicate group. The layered silicate materials, with their ability to absorb and exchange metal ions, water molecules and other substances strongly affect soil, chemistry, biological mineralisation cycles and weathering.

Plasticity, grain size distribution and the mineral composition define the quality and properties of the end product of clay. The variation in mineralogical and engineering properties of clays depends on the make-up of the parent rock, topography, cliamte, vegetation, length of weathering and other factors. [5] indicated that the mineralogical composition of soil is responsible for all the engineering properties such as specific gravity, shear strength, Atterberg limits, petrophysical properties and soil classification. Since the mineral composition and texture of pre-existing rocks determine the characteristics of the soil which are all a function of the types of soils and their grain size distribution. The use of X-ray diffraction for mineralogical characterization of soils had been demonstrated for various engineering structures and excavations [6]. Clay minerals found naturally in soils and rocks are among the most reactive silicates and important minerals that affect the engineering behaviour of soils and rocks both as materials of construction and as foundation materials. Identification, characterization and understanding of properties of different clay minerals can aid in assessing the soils for classification and engineering performance. The mineralogical composition of a parent rock is a pointer to the composition of soils developed over it [7]. 
The dominance of clay deposits in Nigeria, most especially in the study area is due to an important condition of the tropical climate characterized by alternating dry and wet seasons and relatively high humidity that encouraged intensive weathering. Unfortunately, Erusu clay deposits are unidentified, uncharacterized and underutilized due to little or no geological information on the engineering properties and mineralogical composition of the clay bodies. The principal minerals in a deposit of clay tend to influence its swell-shrink and engineering behaviour. The highest volume changing clay is the montmorillonite group (smectites). Calcium montmorillonite and sodium montmorillonite (bentonite) are two types of montmorillonite, but sodium montmorillonite is more expansive and less common. These volume changing clays are generally present all over the world being the cause of most natural hazards like foundation problems causing damage to structures, roads, services and rock instability causing land slides. The more mineralogical and geotechnical data that are available on clay bodies, the better, as this can lead to more effective understanding of their engineering performance and industrial suitability. A better understanding of the nature of clay and their mineralogical composition would make possible a more precise prediction of behaviour and many of the problems encountered in engineering practice would be avoided. Due to rapid development of the town, building and infrastructure projects demand a comprehensive understanding of the indigenous clay deposits, hence the need for raw materials in the area to support industrial growth to aid socio-economic development of the community. The focus of this work is to investigate clay deposits around Erusu Akoko with a view to establish their geotechnical properties and characterize the clay mineral suites in the clays.

\section{Description of the Study Area}

The ancient town of Erusu Akoko is located within the North Senatorial district of Ondo State, Nigeria. It lies between latitudes $7^{\circ} 30^{\prime} \mathrm{N}$ and $7^{\circ} 35^{\prime} \mathrm{N}$ and longitudes $5^{\circ} 45^{\prime} \mathrm{E}$ and $5^{\circ} 50^{\prime} \mathrm{E}$ (Fig. 1). The town is situated in the humid tropical region of Nigeria, characterized by alternating wet and dry seasons with a mean annual rainfall of over $1500 \mathrm{~mm}$. The area is also characterized with a fairly uniform temperature and high relative humidity [8]. The inhabitants of this town are mainly indigenous of the town, students and government workers. This restricts their occupation mainly to farming, schooling and civil service. The area is majorly drained by River Auga and other streams which are seasonal. The river dominates the drainage system of the study area and it's mainly dendritic. The area is moderately to highly undulating with an average surface elevation of about $362 \mathrm{~m}$.

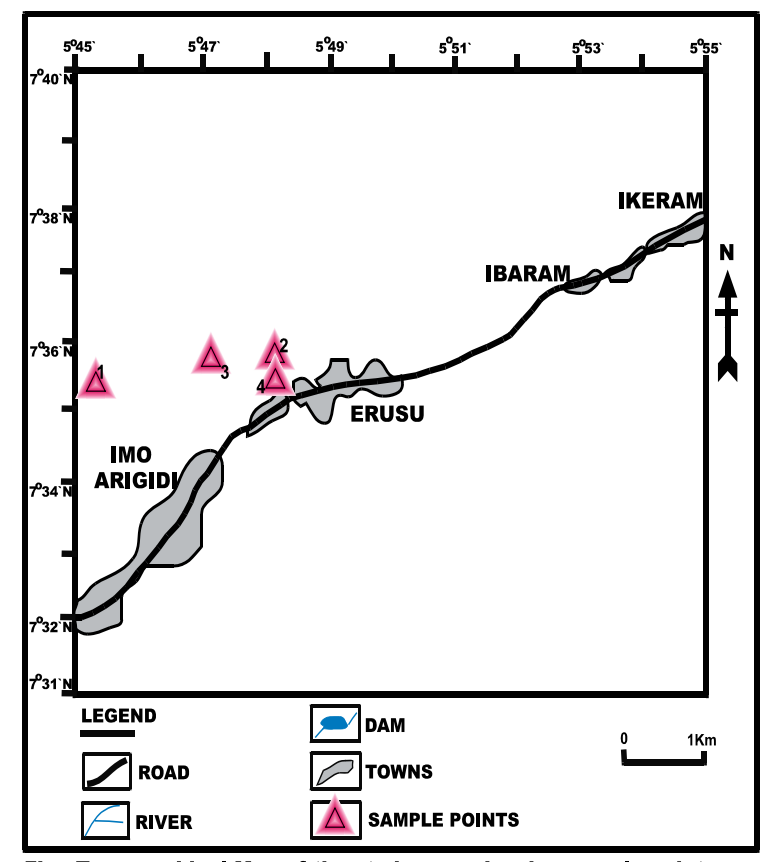

Figure 1. Location map of the study area 
Geologically, the study area falls within the Precambrian Basement Complex rocks of southwestern Nigeria. It is underlain by migmatite-gneiss-quartzite complex with the granite gneiss being the major rock unit (Fig. 2) with minor amount of porphyritic granite, augen gneiss and charnockite. Granite gneiss is the metamorphosed granites, widely distributed in the study area and it is of two types; the biotite rich gneiss and the banded gneiss. The biotite rich gneiss is fine to medium grained and show strong foliation trending westwards and is usually dark in colour. The banded gneiss shows parallel alignment and alteration. It occurs mostly as hills, boulders and flat lying exposures which are dark to light grey in colour and porphyroblastic in texture. There are several quartzite intrusions cutting across the granite. Grey gneiss in the study area varies from light to dark grey. Different textural varieties have been recognized but the most common type is a medium grained rock with regular and persistent banding of varying thickness. The gneissic rocks occur as highly weathered and low-lying outcrop. The granite rocks are of the older granite suite. Based on the textural characteristics, there are fine-grained biotite granite, medium to coarse porphyritic biotite-hornblend granite. Migmatite gneiss is the predominant rock unit that underlies the study area.

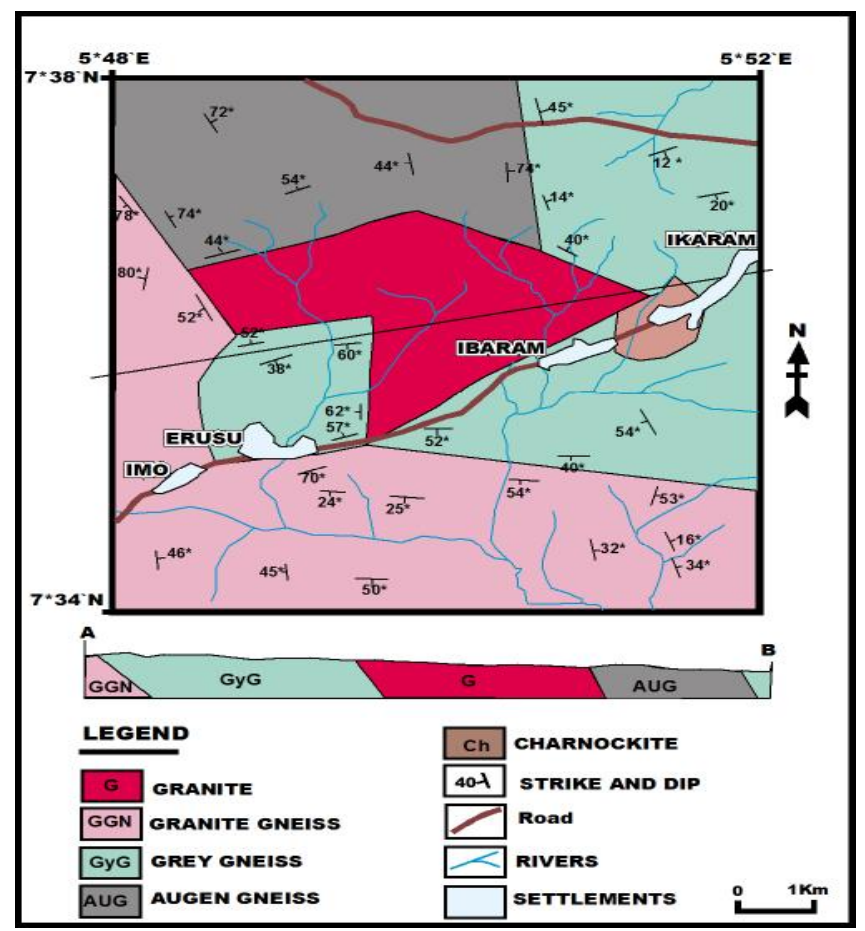

Figure 2. Geological map of Erusu Akoko

\section{$3 \quad$ Materials and Methods}

\subsection{Sampling and Sample Preparation}

Four representative clay samples were collected from different parts of the clay deposits for this study. The clays were collected at $1.5 \mathrm{~m}$ depth from freshly exposed surfaces of the clay bodies. The exposed surface of the clay was scraped to remove any dirt using a hand trowel. The sample collection was done in a systematic way so as to ensure proper collection of samples and total coverage of the study area. A global positioning system (GPS) was used at each sample station to measure coordinates of the station and heights above sea level. On the field, the clay exposures were observed and described based on their grain sizes, colour and texture. All the clay samples were carefully labeled in sample bags and then taken to the laboratory in sealed polythene bags to prevent contamination and loss of moisture. The samples were prepared for testing by crushing using a jaw crusher, followed by gently grinding the 
samples to avoid destruction of the structure of the mineral constituents. Prepared samples were airdried for two weeks immediately after removing samples for the determination of moisture content to facilitate the sieving process in the laboratory for geotechnical investigation and clay mineralogical analysis.

\subsection{Geotechnical Tests}

The index and engineering properties determined on representative samples included natural moisture content, specific gravity, grain-size distribution, consistency limits, compaction test, California Bearing Ratio tests and firing test. The procedures adopted for tests are in accordance with $[9,10]$ test procedures.

\subsection{Mineralogical Investigation}

The clay minerals present in the clay samples were identified using the X-ray power diffraction (XRD) method. X-ray diffraction method is suitable for identifying and quantifying the clay minerals present in soils. It is a rapid analytical technique primarily used for phase identification of a crystalline material. It is also based on constructive interference of X-rays and a crystalline sample. The analysis was conducted using a GBC Enhanced Mini Material Analyzer (EMMA) X-ray diffractometer equipped with $\mathrm{Cu}-\mathrm{K} \alpha$ radiation source and operated at $40 \mathrm{kV}$ and $40 \mathrm{~mA}$. The representative clay samples were step-scanned from $5-65^{\circ}$ at scan speed of $0.02^{\circ} 2 \theta / \mathrm{s}$. The interpretation of the diffractograms of clay samples were based on the comparison of the peaks obtained with those of the standard minerals established by [11].

\section{$4 \quad$ Results and Discussion}

\subsection{Geotechnical Analysis of the Clay Samples}

\subsubsection{Natural Moisture Content}

The moisture content determination is important in understanding the engineering properties of soil for construction and industrial use. The moisture content for L1, L2, L3 and L4 are 13.05\%, 13.50\%, $22.95 \%$ and $29.45 \%$ respectively (Table 1 ). This is a function of the void ratios and the specific gravities of the samples. Although natural moisture content is not a constant property of soils, these values are consistent with the fines contents of the clays. The high moisture content obtained conforms to the generally accepted high porosity and low permeability properties of clay.

\subsubsection{Liquid Limit Determination}

The results (Table 1) show that the liquid limits for L1, L2, L3 and L4 are 52.2\%, 50.4\%, 48.4\% and $48.3 \%$ respectively. Liquid limit less than $30 \%$ indicates low plasticity, between $35 \%$ and $50 \%$ indicates intermediate plasticity, between $50 \%$ and $70 \%$ high plasticity, between $70 \%$ and $90 \%$ indicates very high plasticity and greater than 90\% indicates extremely high plasticity [12]. On the basis of this, L3 and L4 soils are classified to be of intermediate plasticity while the L1 and L2 soils are of high plasticity. [13] stipulated that the liquid limit of soil use for barriers lining should be less than $90 \%$. The determined liquid limits of the studied soils are less than $90 \%$. Thus the soils are expected to exhibit low hydraulic conductivity and are suitable for use as barrier soils.

\subsubsection{Plastic Limit}

The plastic limits of the clays ranged between $18.5 \%$ and $22.25 \%$. This indicates that they are suitable for the production of ceramic clays, as [14] prescribed a range of $10-60 \%$ for clay used in ceramic production. All the samples have values that fall within this specified limit.

\subsubsection{Plasticity Index}

The values of plasticity index (an indicator of soil plasticity) for the studied clay ranged from 26.05 to $31.90 \%$ with L2 having the highest plasticity index of $31.90 \%$ and L4 with the lowest plasticity index of 26.05 (Table 1). The sample L2 has a high liquid limit (50.4\%), low plastic limit (18.5\%) and a high plasticity index $(31.9 \%)$ indicating a high swelling and high compressibility characteristics. The difference in the plasticity index may be due to the presence of montmorillonite clay minerals in the mineralogy of the soil samples. Generally, the high plasticity index showed the clays potential for great 
volume change characteristics. [15] indicated that plasticity index must be greater than $7 \%$ for soils to be suitable for use as barrier materials. The clay soils meet this requirement and the values show that their expansion when in contact with water is minimal, indicating their low permeability and ability to prevent leaching of contaminants generated in the landfill. [16] suggested that there is a notable increase in permeability where materials have a plasticity index of $12 \%$ or less, hence the clay soils under consideration with plasticity index greater than $12 \%$ can be considered suitable for barrier soil as notable increase in permeability is not expected.

\subsubsection{Linear Shrinkage}

The linear shrinkage of the samples increases with increasing firing temperature of the furnace used. The firing shrinkage in a laboratory furnace has a complex relationship with the total mineralogy of the clay in which almost every mineral constituent of the original clay moves apart. The individual grains in a compacted clay material may shrink within themselves at a high temperature, but an overall shrinkage of the clay can occur only when the reaction between adjacent grains takes place [17]. The linear shrinkage values obtained at $1200^{\circ} \mathrm{C}$ varied from $8.5-8.9 \%$ (Table 1 ).

\subsubsection{Specific Gravity}

The specific gravity of the samples ranged from $2.70-2.89$ with an average value of 2.77. Sample L3 had the lowest value of 2.70 while sample L2 had the highest value of 2.89. [18] noted that the specific gravity of soil grains is an important property in the identification and evaluation of aggregate parameters for construction purposes. The higher the specific gravity of the soil, the better it is for construction purposes.

Table 1. Values of natural moisture content (MC), liquid limit (LL), plastic limit (PL), plasticity index (PI), linear shrinkage (LS) and specific gravity (SG) of the clay samples

\begin{tabular}{lllllll}
\hline Location & MC (\%) & LL (\%) & PL (\%) & PI (\%) & LS (\%) & SG \\
\hline L1 & 13.1 & 52.2 & 21.5 & 30.7 & 8.9 & 2.74 \\
L2 & 13.5 & 50.4 & 18.5 & 31.9 & 8.5 & 2.89 \\
L3 & 22.9 & 48.4 & 22.1 & 26.3 & 8.9 & 2.70 \\
L4 & 29.5 & 48.3 & 22.3 & 26.0 & 8.9 & 2.75 \\
\hline
\end{tabular}

\subsubsection{Particle Size Distribution}

The grading characteristics of the studied clay soils are summarized in Table 2. It can be observed that sand fractions dominate the composition of the clay soils. Based on the Unified Soil Classification System (USCS), soils with amount of fines (silt and clay) ranging between 0 and $5 \%$ are generally described as well-graded, while those in the range of $5-15 \%$ are referred to be well-graded clayey sand or gravel. Soils in the range 15-35\% are described as very clayey. On the basis of this, all the studied clay soils are clayey. [15] recommended materials with high clay content or a high silt and clay content as the soils that will display low permeability for a sanitary landfill. Also, [19] recommended that liner soil should contain adequate amount of sand, which may provide enough strength and guide against volumechange behaviour of the soil.

However as noted by [20], soils with amounts of fines less than $50 \%$ are expected to possess better engineering properties while those with amounts of fines greater than $50 \%$ are expected to pose field compaction problems when used either as sub-base or sub-grade materials. Hence it can be suggested on the basis of amounts of fines that, the studied clay can be used as sub-base or sub-grade materials in the construction of roads because of the high percentage of sands. Furthermore, on the basis of the recommendation by the Nigerian Federal Ministry of Works and Housing [21] specification, amounts of fines $\leqslant 35 \%$ are suitable for general filling for highway construction, hence, the materials qualify as general filling materials. The sand content makes the sample materials suitable for large ceramic applications, making building blocks and bricks. 
Table 2. Grain size distribution of the clay soils in the study area

\begin{tabular}{lllll}
\hline Clay Sample & L1 & L2 & L3 & L4 \\
\hline Gravel (\%) & 3.3 & 4.4 & 4.9 & 4.2 \\
Sand (\%) & 63.5 & 68.5 & 70.0 & 65.7 \\
Silt (\%) & 16.2 & 11.8 & 18.1 & 21.1 \\
Clay (\%) & 17.1 & 15.2 & 7.05 & 9.1 \\
Fines (\%) & 33.3 & 27.0 & 25.2 & 30.2 \\
\hline
\end{tabular}

\subsubsection{Compaction}

The maximum dry density (MDD) for the soil samples varied between $1898 \mathrm{Kg} / \mathrm{m}^{3}$ and $1998 \mathrm{Kg} / \mathrm{m}^{3}$ while that of optimum moisture content (OMC) ranged between $11.8 \%$ and $15.3 \%$ (Table 3). The observed results for all the samples show that the higher the MDD, the lower the OMC. The results of the MDD and OMC show that the samples can be used as filling and embankment materials because they fall within the specification by the [21], that MDD should be greater than $1680 \mathrm{~kg} / \mathrm{m}^{3}$ and OMC less than 18\%. Also [22] recommended a minimum MDD of $1650 \mathrm{~kg} / \mathrm{m}^{3}$ for bungalow bricks, indicating that the examined clays are suitable for good brick making materials.

The good values of the compaction properties possessed by these soils make them good engineering construction materials.

\subsubsection{California Bearing Ratio Strength}

The unsoaked CBR value for the clay soil samples ranged from $19.0 \%-30.0 \%$ while the soaked CBR values ranged from $6 \%-9 \%$ (Table 3). None of the analyzed samples have the required $80 \%$ unsoaked and $30 \%$ soaked CBR value recommended for highway sub-base and sub-grade soils by the [21]. The soils showed decreased CBR value after soaking. The soaked CBR falls below the minimum soaked CBR requirement of $30 \%$ for sub-base course. The soil samples do not meet the requirements for both road sub-base and base courses. It shows reduction in strength as a result of soaking of the compacted samples. This is an indication that, moisture influx and ingress of water would be harmful to sub-grades of pavements and foundations of other engineering structures constructed with these clays.

Table 3. Summary of the compaction and CBR results

\begin{tabular}{lllll}
\hline Location & $\begin{array}{l}\text { Optimum Moisture } \\
\text { Content (\%) }\end{array}$ & $\begin{array}{l}\text { Maximum Dry } \\
\text { Density }\left(\mathbf{K g} / \mathbf{m}^{3}\right)\end{array}$ & $\begin{array}{l}\text { Unsoaked } \\
\text { CBR(\%) }\end{array}$ & $\begin{array}{l}\text { Soaked } \\
\text { CBR (\%) }\end{array}$ \\
\hline L1 & 11.8 & 1998 & 22.5 & 6 \\
L2 & 15.3 & 1898 & 22.5 & 7 \\
L3 & 13.0 & 1942 & 30 & 9 \\
L4 & 12.05 & 1966 & 19 & 8 \\
\hline
\end{tabular}

\subsubsection{Firing Test}

The values for all the four samples ranged between $1250^{\circ} \mathrm{C}$ and $1500^{\circ} \mathrm{C}$. This temperature is an indication of moderate refractoriness because the normal range for a fire clay brick is between $1580^{\circ} \mathrm{C}-$ $1750^{\circ} \mathrm{C}$ as recommended by [14]. These values of refractoriness may be as a result of the high silica content of the clay. The effect of this is that, its use is restricted to the processing of materials which melting points do not exceed $1500^{\circ} \mathrm{C}$.

\subsection{Mineralogical Composition}

Geotechnical characteristics of clayey soils are often associated with their mineralogical composition, especially with clay mineralogy. The spectra and main diagnostic peaks used for their identification are shown in Figures 3 - 6 respectively. The names of the minerals, their chemical formula, D space, counts, relative intensity and glancing angle are given below each of the spectrum. X-ray powder diffraction analysis for L1 (Okesan-Imo) detected dominantly the presence of Illite-smectite mineral identified as rectorite $\left(\mathrm{K}_{12} \mathrm{Al}_{4} \mathrm{Si}_{8} \mathrm{O}_{20}(\mathrm{OH})_{4} \cdot 4 \mathrm{H}_{2} \mathrm{O}\right)$, berlinite $\left(\mathrm{AlPO}_{4}\right)$ and quartz $\left(\mathrm{SiO}_{2}\right)$ (Table 4). However illite is also present in minor quantities. The presence of smectite is important due to its high swelling ability, 
which could make a soil unsuitable as sub-grade or building foundation material. Although, illite is also present in the sample, which occurs only as a minor mineral and thus possesses no threat as they are non-swelling clays.

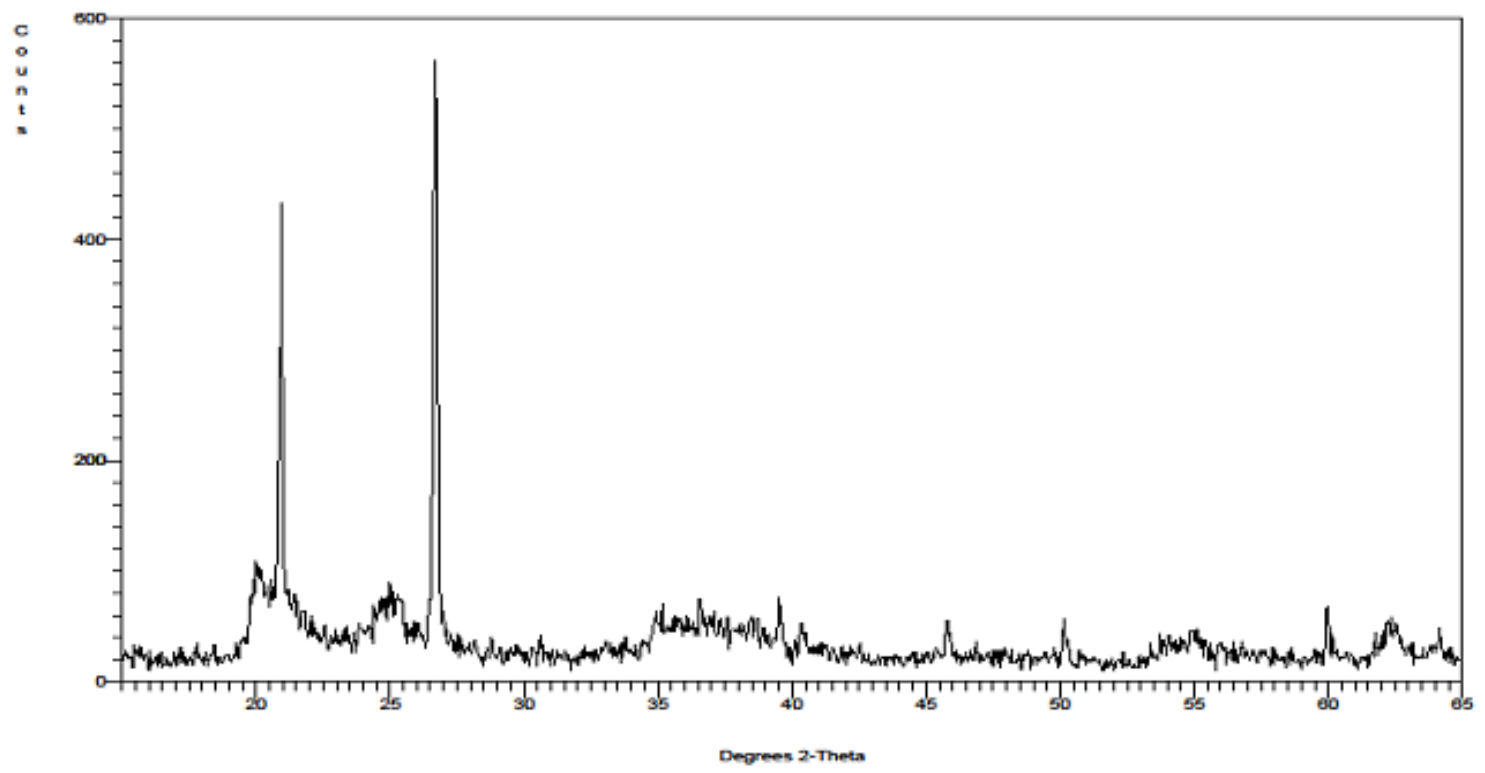

Figure 3. XRD diffractogram of sample of Location 1

Table 4. Structural parameters of sample of Location 1

\begin{tabular}{llllll}
\hline Angle & Counts & D space & Relative intensity & Mineral name & Chemical formula \\
\hline 20.07 & 109 & 4.421 & 19 & Quartz & $\mathrm{SiO}_{2}$ \\
20.946 & 432 & 4.4238 & 77 & Berlinite & $\mathrm{AlPO}_{4}$ \\
25.25 & 78 & 3.524 & 14 & Rectorite & $\mathrm{K}_{1.2} \mathrm{Al}_{4} \mathrm{Si}_{8} \mathrm{O}_{20}(\mathrm{O} \mathrm{H})_{4} \cdot 4 \mathrm{H}_{2} \mathrm{O}$ \\
26.051 & 52 & 2.418 & 9 & Illite & $\mathrm{K}-\mathrm{Na}-\mathrm{Mg}-\mathrm{Fe}-\mathrm{Al}-\mathrm{Si}-\mathrm{O}-\mathrm{H}_{2} \mathrm{O}$ \\
26.702 & 561 & 3.336 & 100 & Rectorite & $\mathrm{K}_{1.2} \mathrm{Al}_{4} \mathrm{Si}_{8} \mathrm{O}_{20}(\mathrm{O} \mathrm{H})_{4} \cdot 4 \mathrm{H}_{2} \mathrm{O}$ \\
\hline
\end{tabular}

Sample of location L2 has the highest intensities of zirconium titanium phosphate and montmorillonite with berlinite and low quartz content (Table 5). The occurrence of montmorillonite in the sample is attributed to a swelling clay group with high plasticity which is a characteristic of Ball clays. Swelling clays such as vermiculites and montmorillonites are formed in areas of poor drainage and alkali conditions [23].

The diffraction pattern for sample L3 (Okesan) shown in Fig. 5 revealed halloysite (hydrated) and serpentine which belong to the kaolinite group as the only clay minerals with berlinite, quartz and fluckite (Table 6) which are non- clay minerals in the sample. Good drainage and slightly acidic conditions favour the formation of the clay containing stable clay minerals such as kaolinite. These conditions exist in all the locations where the samples were taken except in location 2.

The diffraction pattern for sample L4 (Aga) is shown in Fig. 6. The diffraction chart indicated kaolinite as the major mineral phase having the highest peak in the sample (Table 7). The clay may be used for coating papers due to its high proportion of kaolinite. Other minerals identified are: tiemannite, argentite, quartz, berlinite and despujolsite.

The X-ray diffraction (XRD) analyses of the clay samples revealed that quartz and berlinite are present in all the samples. Consequently, the high quartz content revealed by the X-ray diffraction accounts for the high percentage of sand size fraction observed in the grain size distribution. The clay samples may be suitable for brick making because of the presence of quartz in significant amounts which gives strength and durability to bricks. This is attributable to the fact that during the vitrification 
period, quartz combines with the basic oxides of the fluxes released from the clay minerals on firing to form glass, which improves the strength [24].

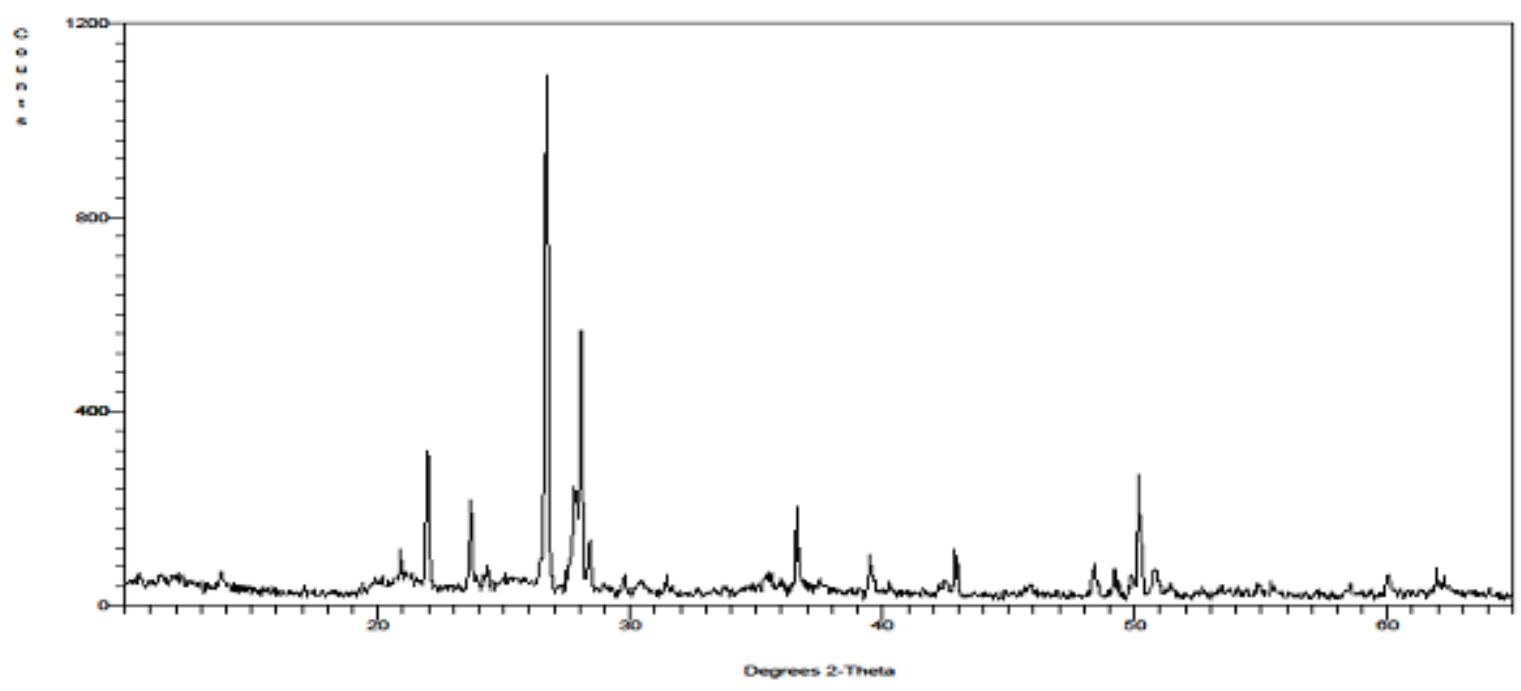

Figure 4. XRD diffractogram of sample of Location 2

Table 5. Structural parameters of sample of Location 2

\begin{tabular}{|c|c|c|c|c|c|}
\hline Angle & Counts & $\begin{array}{l}\mathrm{D} \\
\text { space }\end{array}$ & $\begin{array}{l}\text { Relative } \\
\text { intensity }\end{array}$ & Mineral names & Chemical formula \\
\hline 20.9 & 117 & 4.247 & 11 & Quartz, low & $\mathrm{SiO}_{2}$ \\
\hline 21.974 & 318 & 4.042 & 29 & Berlinite & $\mathrm{AlPO}_{4}$ \\
\hline 23.692 & 217 & 3.752 & 20 & $\begin{array}{l}\text { Magnesium Manganese } \\
\text { Arsenide }\end{array}$ & $\mathrm{MnMg}_{2} \mathrm{As}_{2}$ \\
\hline 26.688 & 1092 & 3.338 & 100 & $\begin{array}{l}\text { Zirconium Titanium } \\
\text { Phosphate }\end{array}$ & $\mathrm{Zr}_{0.2} \mathrm{Ti}_{0.8} \mathrm{P}_{2} \mathrm{O}_{7}$ \\
\hline 28.049 & 566 & 3.179 & 52 & Montmorillonite & $(\mathrm{Na}, \mathrm{Ca})(\mathrm{Al}, \mathrm{Mg})_{6}\left(\mathrm{Si}_{4} \mathrm{O}_{10}\right)_{3}(\mathrm{OH})$ \\
\hline 36.599 & 203 & 2.453 & 19 & Malladrite & $\mathrm{F}_{6} \mathrm{Na}_{2} \mathrm{Si}$ \\
\hline
\end{tabular}

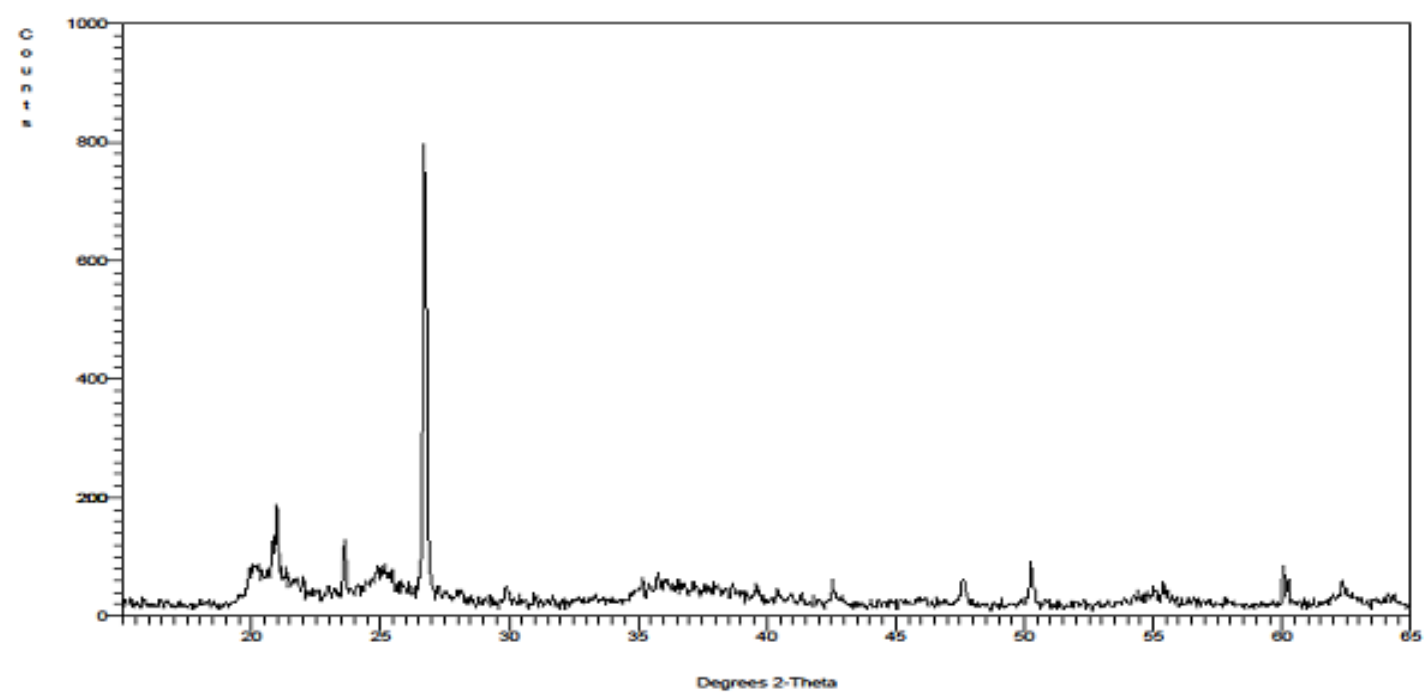

Figure 5. XRD diffractogram of sample of Location 3 
Table 6. Structural parameters of sample of Location 3

\begin{tabular}{llllll}
\hline Angle & Counts & D space & Relative intensity & Mineral name & Chemical formula \\
\hline 20.132 & 88 & 4.407 & 11 & Quartz, low & $\mathrm{SiO}_{2}$ \\
20.975 & 187 & 4.232 & 23 & Berlinite & $\mathrm{AlPO}_{4}$ \\
23.618 & 129 & 3.764 & 16 & Quartz & $\mathrm{SiO}_{2}$ \\
25.107 & 85 & 3.544 & 11 & Fluckite & $\mathrm{CaMn}_{2}\left(\mathrm{HAsO}_{4}\right)_{2} \cdot 2 \mathrm{H}_{2} \mathrm{O}$ \\
26.723 & 796 & 3.333 & 100 & Halloysite, hydrated & $\mathrm{Al}_{2} \mathrm{Si}_{2} \mathrm{O}_{5}(\mathrm{OH})_{4} \cdot 2 \mathrm{H}_{2} \mathrm{O}$ \\
50.25 & 91 & 1.814 & 11 & Quartz, low & $\mathrm{SiO}_{2}$ \\
60.064 & 85 & 1.539 & 11 & Serpentine & $(\mathrm{Mg}, \mathrm{Fe})_{3}, \mathrm{Si}_{2} \mathrm{O}_{5}(\mathrm{OH})_{4}$ \\
\hline
\end{tabular}

\section{Conclusion}

Fundamental understanding of the engineering behaviour of clays is provided by studying the geotechnical properties and mineralogy of the clay samples from different locations of the study area. The unified classification of the samples deduces that the clay samples have limited industrial potential because of the silt contents. However, the samples are granular materials with plasticity index greater than $12 \%$ which may be considered suitable for barrier soil as notable increase in permeability is not expected. All the samples of the study area have high concentration of fine material (clay + silt) having high plasticity and can be used to make structural blocks, bricks or roof tiles. The moderate linear shrinkage, compaction characteristics of the clay soils is considered suitable for large ceramic applications and good brick materials. On the basis of the recommendation by [21] specification, the materials qualify as general filling materials. The CBR test shows that the entire studied soil did not meet up the general specification requirements for roads and bridges. The high quartz content revealed by the X-ray diffraction accounts for the high percentage of sand size fraction observed in the grain size distribution. The clay samples may be suitable for brick making because of the presence of quartz in significant amounts which gives strength and durability to bricks. Assessment of the industrial potentials of the clay bodies based on their geotechnical and mineralogical characteristics suggests that they are suitable for the production of refractory bricks and ceramics, other industrial applications, such as rubber, paper, paint, cosmetics, and fertilizers would require appropriate and thorough processing.

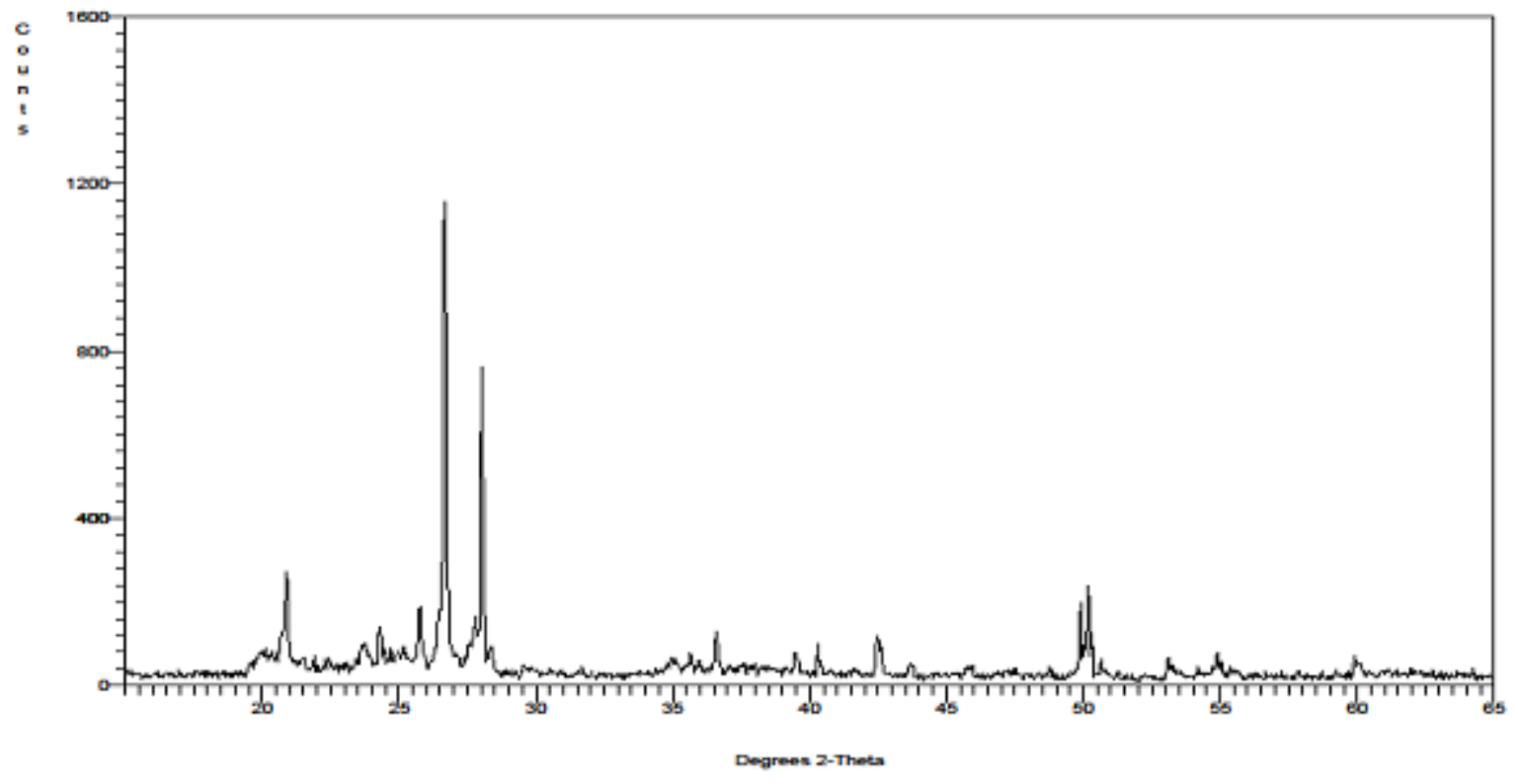

Figure 6. XRD diffractogram of sample of Location 4 
Table 7. Structural parameters of sample of Location 4

\begin{tabular}{llllll}
\hline Angle & Counts & D space & Relative intensity & Mineral name & Chemical formula \\
\hline 20.887 & 271 & 4.249 & 23 & Argentite & $\mathrm{Ag}_{2} \mathrm{~S}$ \\
23.75 & 100 & 3.743 & 9 & Quartz & $\mathrm{SiO}_{2}$ \\
24.3 & 141 & 3.66 & 12 & Berlinite & $\mathrm{AlPO}_{4}$ \\
25.754 & 189 & 3.456 & 16 & Despujolsite & $\mathrm{Ca}_{3} \mathrm{Mn}_{4}(\mathrm{SO} 4)_{4}(\mathrm{OH})_{6} \cdot 3 \mathrm{H}_{2} \mathrm{O}$ \\
26.675 & 1159 & 3.339 & 100 & Kaolinite & $\mathrm{Al}_{4} \mathrm{Si}_{4} \mathrm{O}_{10}(\mathrm{OH})_{8}$ \\
28.01 & 764 & 3.183 & 66 & Tiemannite & $\mathrm{HgSe}$ \\
36.585 & 130 & 2.454 & 11 & Berlinite & $\mathrm{AlPO}_{4}$ \\
50.17 & 240 & 1.817 & 21 & Quartz, low & $\mathrm{SiO}_{2}$ \\
\hline
\end{tabular}

\section{References}

1. C. Atalar, and R. Kilic, "Geotechnical properties of Cyprus clays," Bulletin of the International Association of Engineering Geology, pp. 419, 2006.

2. J. O. Ajayi, and O. K. Agagu, "Mineralogy of primary clay deposits in the basement complex areas of Nigeria," Journal of Mining and Geology, 18(1), pp. 27-30, 1981.

3. B. Velde, "Composition and mineralogy of clay minerals," in: B. Velde (ed.), Origin and mineralogy of clays. New York, Springer-Verlag, pp. 8-42, 1995.

4. W. T. Bakker, "Refractories for present and future electric power plants," Key engineering materials, Trans Technology Publications, vol. 88, pp. 41-70, 1993.

5. U. Shafique, M. S. Khan, A. Mustafa, and S. Arif, "Engineering geological characterization of Lahore soil, based on geotechnical testing and mineralogical composition using X-ray diffraction," Pakistan Journal of Science, vol. 64, no. 3, pp. 191-195, 2012.

6. S. Kibria, S. Saeed, and A. Akbar, "A comparative study of pile-anchor support system for deep excavations in Lahore," Proceeding of the international conference on geotechnical engineering, Lahore, 5-6 November, 2010, pp. 121-128.

7. G. J. J. Aleva, "Laterites: concepts, geology, morphology and chemistry, Wegeningen." The Northerlands: ISRC, 1994, pp. 169.

8. Nigeria Meteorological Agency, NIMET, "Daily weather forecast on the Nigerian Television Authority," Nigerian Metrological Agency, Oshodi, Lagos, Nigeria, 2007.

9. BS1377 Methods of test for soils for civil engineering purposes. British standards Institute, London. 2, Park Street London WI A2BS, 1990.

10. American Standard Test Method (ASTM), "Standard method for classification of soils for engineering purposes," (Unified Soil Classification System), pp. 12, 2006.

11. Joint Committee on Powder Diffraction Standards (JCPDS), "Mineral powder diffraction file," vol. I and II. Published by International Centre for Diffraction Data, Parklane, USA, 1980.

12. R. Whitlow, "Basic soil mechanics," $3^{\text {rd }}$ Edition Addison Wesley Longman Limited, Edinburgh gate, 1995.

13. O. Declan, and Q. Paul, "Geotechnical engineering and environmental aspects of clay liners for landfill projects," Technical paper 3, Fehily Timoney and Co. and IGSL limited, 2003.

14. R. W. Grimshaw, "The Chemistry and Physics of clays and allied ceramic materials," $3^{\text {rd }}$ Edition, Ernest Benn Limited, pp. 801-802, 1971.

15. R. K. Rowe, R. M. Quigley, and J. R. Booker, "Clayey barrier systems for waste disposal facilities," $E$ and $F N$ Spon, London, 1995.

16. E. J. Murray, D. W. Rix, and R. D. Humphrey, "Clay lining to landfill sites," Quarterly Journal of Engineering Geology, vol. 25, no. 4, pp. 371-376, 1992.

17. J. E. Prentice, "Evaluation of brick clay reserves," Applied Earth Science, section, 8(197), pp. 9-14, 1988.

18. M. D. Gidigasu, "Laterite soil engineering pedo-genesis and engineering principles," Amsterdam Elsevier Scientific, New York, pp. 554, 1976.

19. M. H. Kabir, and M. R. Taha, "Assessment of physical properties of a granite residual soil as an isolation barrier," Electronic Journal of Geotechnical Engineering, vol. 92c, pp. 13, 2004. 
20. I. A. Oyediran, and T. O. Williams, "Geotechnical properties of some banded gneiss derived lateritic soils from Ibadan, Southwestern Nigeria," Journal of Science Research, vol. 9, no. 2, pp. 62-68, 2010.

21. Federal Ministry of Works and Housing, "Specification for roads and bridges," vol. 2, pp. 137-275, 2000.

22. A. C. Madedor, "The impact of building materials research on low cost housing development in Nigeria," Engineering Focus. Publication of the Nigerian Society of Engineers, vol. 4(2) April-June, pp. 37-41, 1992.

23. M. M. Duane, and C. R. Robert, "X-ray diffraction and the identification analysis of clay minerals." $2^{\text {nd }}$ edition. Oxford University Press, 1997.

24. F. G. Bell, "Engineering Properties of Soils and Rocks," 4th Ed. Oxford, Blackwell Science, pp. 482, 2000. 